\title{
Temporal Variation of Leucaena Leucocephala Seedlings in Soil Conservation and Slope Protection
}

\author{
Ling Bai \\ College of biological \& pharmaceutical, China Three \\ Gorges University \\ Yichang China \\ email:bailing529@qq.com \\ Fangqing Chen \\ College of biological \& pharmaceutical, China Three \\ Gorges University \\ Yichang China \\ email: fqchen@ctgu.edu.cn
}

\author{
Yu Huang \\ Yichang Environmental Monitoring Station \\ Yichang China \\ email: a183620649@qq.com
}

\begin{abstract}
Leucaena leucocephala has been widely used in the ecological restoration and protection of engineering slopes in southwest hydropower projects. It is one of the key issues in slope ecological restoration that how to determine seeding age for transplantation. The erosion resistance, scour resistance, shear strength of soil-fibrous root systems and tensile strength of root systems were tested to evaluate the effects of $L$. leucocephala seedlings on soil conservation and slope protection and its temporal variation within 12 months after being planted. The results showed that the average height and root biomass of $L$. leucocephala seedlings reached $208.1 \mathrm{~cm}$ and $46.6 \mathrm{~g}$. The erosion resistance, scour resistance and shear strength of its soil-root system were increased by $288.4 \%, 198.6 \%$ and $226.4 \%$ contrast with that of the control, respectively. The effects of its soil-root system on soil conservation and slope stabilization increased with the prolonging of plant growth time constantly, and during six month to seven, it grow the fastest. Correlation analysis indicated that the performance of soil root systems had significant positive correlation with root system biomass. It suggested that the differences in root system biomass caused the changes of root systems in soil conservation and slope stabilization. L. leucocephala seedlings over seven month old had very obvious effects on soil conservation and slope stabilization with good ability to establish, can be used practically for the ecological restoration of engineering slopes.
\end{abstract}

Keywords-Soil conservation and slope stabilization; Leucaena leucocephala seeding; ecological restoration; soil root system; Biomass.

Plant root system can conserve soil and strengthen slope by improving the scour resistance, erosion resistance and shear strength of soil through root network [1]. Leucaena leucocephala is an evergreen small tree belonging to Leucaena genus of Fabaceae family. It has been largely used in the ecological restoration projects with developed root system, rigorous plant growth, strong fecundity and adaptation [2]. Previous studies showed that the anchor ability of its fast-growing tap root system could significantly improve the shear strength of soil [3]. Since the performance of vegetation on soil conservation and slope protection was comprehensively implemented through root-soil system of plant communities. Plants in different ages with different root systems would really make great different effects [4]. This paper focused on root system's growth and development of L. Leucocephala seedlings, temporal variation of soil-root system on soil conservation and slope protection, and the correlation between the index of root system in soil conservation and slope protection and root biomass. All these research data were scientifically analyzed to evaluate the effects and the variation of L. leucocephala seedlings' soil-root system on soil conservation and slope stabilization, and determine whether or not it could be used for ecological recovery of engineering slopes.

\section{MATERIAL AND METHODS}

\section{A. Field experimental design}

The experimental plot included 12 standard quadrats ( $1.5 \mathrm{~m}$ in width, $3 \mathrm{~m}$ in length). 11 quadrats were used for planting experiment and one quadrat as the control. Holes in specification of $0.5 \mathrm{~m} \times 0.5 \mathrm{~m}$ were dug out at each planting quadrat Five seeds were planted in each hole. After germination, the strongest seedling in each hole was kept for experiment and the rests were cleared up. 15 plants were sampled randomly per month after planting three month to test the growth of above ground part, so did their soil root system using soil drill (Depth: $10 \mathrm{~cm}$, Diameter: $8 \mathrm{~cm}$ ) to test the erosion resistance, scour resistance, and shear strength. A control soil sample was collected and tested at the same time.
B. Determination of soil reinforcement and slope protection
1 Test of soil erosion resistance 
Enhancement of soil erosion resistance of the soil-root system was measured using the method of the collapse resistant in static water and calculated as following [6]: $\mathrm{Ce}$ $=\left(\mathrm{V}_{1}-\mathrm{V}_{2}\right) / \mathrm{V}_{2}$. Ce is the enhancement of erosion resistance of soil-root system ranging from 0 to $1 . V_{1}$ and $V_{2}$ are the detachment rate of the soil-root system sample and control soil sample, respectively. 5 samples and 2 control samples were tested per month.

2 Test of Soil Scour Resistance

Enhancement of soil scour resistance of the soil-root system was measured using the method of scouring soil samples with hydraulic flume based on following calculation: $\mathrm{Ev}=\left(\mathrm{C}_{1}-\mathrm{C}_{2}\right) / \mathrm{C}_{2} . \mathrm{Ev}$ is the enhancement of roots scour resistance of soil-root system. $\mathrm{C}_{1}$ and $\mathrm{C}_{2}$ are the scour resistance coefficients of soil-root system and control sample, respectively. The measurement unit of scour resistance coefficient is the amount of water $(\mathrm{L})$ to flush out $1 \mathrm{~g}$ of saturated sample soil. 5 samples and 2 control samples were tested per month.

\section{Test of Shear Strength}

Soil shear strength of the soil-root system was measured based Mohr-Coulomb law: $\tau=\sigma \tan \varphi+C$ [6]. $\mathrm{C}$ presents effective soil cohesion $[\mathrm{kPa}]$ including the cohesion among soil particles and the cohesion between soil particles and roots; $\sigma$ is effective stress force that is normal to the slope $[\mathrm{kPa}] ; \varphi$ is effective angle of shear resistance. Soil shearing stress $(\tau)$ was calculated by the formula: $\tau=K R$. Soil shear resistance indices $(C, \varphi)$ are determined according to the $\tau-\sigma$ curve. Soil shearing stress was tested using the strain-controlled direct shear apparatus. 5 samples and 2 control samples were tested per month.

\section{Test of tensile strength}

The Diti method was used to test the tensile strength of roots [6]: $\mathrm{P}=4 \mathrm{~F} / \pi \mathrm{D}^{2} . \mathrm{F}$ and $\mathrm{D}$ represent the maximum tensile resistance and diameter of the section of root, respectively. Five plants were measured per month.

\section{E. Test of root system structure}

After finished all the above experiments, remove soil, collect and clean all the root, and use scanner to determine the root area, root length and root furcation number of the collected root on record. Then, plants were dried to a constant mass at $60{ }^{\circ} \mathrm{C}$ in an oven, and weighed to test their biomass.

\section{F. Data analysis}

One-way analysis of variance (ANOVA) was performed to determine the structure of roots and the effects of the soil-root system on soil conservation and slope protection. The relationship of spatial distribution between root structure and the performance of the soilroot system in soil conservation and slope protection was uncovered by linear analysis of root biomass with enhancement of soil erosion resistance, enhancement of soil scour resistance and shear strength, respectively. All analyses were conducted using SPSS software (13.0).

\section{RESULTS AND ANALYSIS}

\section{A. The dynamic change of seedling growth and root structure}

There are significant differences among seedlings with different growth time in root length, root area, furcation number and root biomass of root system $(\mathrm{P}<0.01)$ (Table 1). The indices of L. Leucocephala seedlings increased with the increasing age. Plant height, root length, root area, root biomass and root furcation number of seven-monthold seedling was all increased most fast, which was higher than that of six-month-old plantation by $84.13 \%, 26.89 \%$, $28.24 \%, 145.62 \%$ and $44.93 \%$.

\section{TABLE 1 THE DYNAMIC CHANGE OF SEEDLING GROWTH AND ROOT STRUCTURE FEATURE}

\begin{tabular}{|c|c|c|c|c|c|}
\hline $\begin{array}{l}\text { Seeding } \\
\text { age }\end{array}$ & $\begin{array}{l}\text { Height } \\
(\mathrm{cm})\end{array}$ & $\begin{array}{l}\text { Root length } \\
\text { (cm) }\end{array}$ & $\begin{array}{l}\text { Root area } \\
\qquad(\mathrm{cm} 2)\end{array}$ & $\begin{array}{c}\text { Root } \\
\text { furcation } \\
\text { number }\end{array}$ & $\begin{array}{c}\text { Root } \\
\text { bioma } \\
\text { ss } \\
(\mathrm{g})\end{array}$ \\
\hline 3 month & $5.92 \pm 0.42 \mathrm{a}$ & $10.58 \pm 0.63 a$ & $31.95 \pm 2.95 \mathrm{a}$ & $\begin{array}{c}0.84 \pm 0.4 \\
0 \mathrm{a}\end{array}$ & $\begin{array}{c}0.19 \pm 0 \\
.01 \mathrm{a}\end{array}$ \\
\hline 4 month & $\begin{array}{c}17.61 \pm 1.21 \\
b\end{array}$ & $58.76 \pm 2.73 b$ & $186.63 \pm 5.13 b$ & $\begin{array}{c}2.00 \pm 0.3 \\
2 b\end{array}$ & $\begin{array}{c}0.24 \pm 0 \\
.02 \mathrm{a}\end{array}$ \\
\hline 5 month & $\begin{array}{c}46.82 \pm 3.34 \\
\mathrm{~b}\end{array}$ & $64.08 \pm 1.17 \mathrm{~b}$ & $201.59 \pm 2.68 b$ & $\begin{array}{c}3.42 \pm 0.8 \\
1 \mathrm{bc}\end{array}$ & $\begin{array}{c}6.51 \pm 0 \\
.33 \mathrm{~b}\end{array}$ \\
\hline 6 month & $\begin{array}{c}86.21 \pm 1.85 \\
\mathrm{c}\end{array}$ & $81.31 \pm 3.79 c$ & $\begin{array}{c}258.51 \pm 12.66 \\
\text { bc }\end{array}$ & $\begin{array}{c}4.83 \pm 1.6 \\
8 \mathrm{bc}\end{array}$ & $\begin{array}{l}15.99 \pm \\
1.00 \mathrm{~b}\end{array}$ \\
\hline $\begin{array}{l}7 \text { month- } \\
\text { old }\end{array}$ & $\begin{array}{c}126.60 \pm 3.0 \\
2 \mathrm{c}\end{array}$ & $\begin{array}{c}96.28 \pm 5.07 \mathrm{c} \\
\mathrm{d}\end{array}$ & $\begin{array}{c}278.71 \pm 14.96 \\
\mathrm{c}\end{array}$ & $\begin{array}{c}7.00 \pm 1.3 \\
4 \mathrm{bc}\end{array}$ & $\begin{array}{l}32.41 \pm \\
2.07 \mathrm{c}\end{array}$ \\
\hline 8 month & $\begin{array}{c}135.81 \pm 2.1 \\
3 \mathrm{~cd}\end{array}$ & $\begin{array}{c}106.22 \pm 1.99 \\
\mathrm{~d}\end{array}$ & $\begin{array}{c}280.19 \pm 14.52 \\
\text { c }\end{array}$ & $\begin{array}{c}7.40 \pm 2.4 \\
9 \mathrm{c}\end{array}$ & $\begin{array}{l}37.45 \pm \\
2.90 \mathrm{~cd}\end{array}$ \\
\hline 9 month & $\begin{array}{c}150.54 \pm 3.4 \\
3 \mathrm{~d}\end{array}$ & $\begin{array}{c}108.83 \pm 0.60 \\
\mathrm{~d}\end{array}$ & $\begin{array}{c}287.71 \pm 5.37 \mathrm{c} \\
\mathrm{d}\end{array}$ & $\begin{array}{c}9.83 \pm 2.7 \\
0 \mathrm{c}\end{array}$ & $\begin{array}{r}40.37 \pm \\
1.19 \mathrm{~d}\end{array}$ \\
\hline $\begin{array}{c}10 \\
\text { month }\end{array}$ & $\begin{array}{c}166.00 \pm 2.0 \\
7 \mathrm{~d}\end{array}$ & $\begin{array}{c}109.43 \pm 1.35 \\
\mathrm{~d}\end{array}$ & $291.60 \pm 5.66 \mathrm{~d}$ & $\begin{array}{c}5.60 \pm 1.6 \\
2 \mathrm{~d}\end{array}$ & $\begin{array}{c}44.14 \pm \\
0.30 \mathrm{~d}\end{array}$ \\
\hline $\begin{array}{c}11 \\
\text { month }\end{array}$ & $\begin{array}{c}182.22 \pm 4.1 \\
4 \mathrm{~d}\end{array}$ & $\begin{array}{c}111.01 \pm 0.93 \\
\mathrm{~d}\end{array}$ & $295.43 \pm 3.44 d$ & $\begin{array}{c}7.80 \pm 1.5 \\
3 \mathrm{~d}\end{array}$ & $\begin{array}{r}46.64 \pm \\
0.55 \mathrm{~d}\end{array}$ \\
\hline $\begin{array}{l}\text { F value; } \\
\text { Significa } \\
\text { nce }\end{array}$ & $\begin{array}{c}25.22 \\
0.000 * *\end{array}$ & $\begin{array}{l}43.13 \\
0.000^{*} \\
*\end{array}$ & $\begin{array}{c}36.87 \\
0.000 * *\end{array}$ & $\begin{array}{c}3.20 \\
; \\
0.00 \\
7 * *\end{array}$ & $\begin{array}{r}1 \\
2.07 \\
0 \\
000 * *\end{array}$ \\
\hline
\end{tabular}

B. Effects and spatial variation of soil reinforcement and slope protection

1) Erosion Resistance of Soil Root System

The existence of plant root system significantly decreased the soil detachment rate, and improved its erosion resistance. The detachment rate and erosion reinforcement of $\mathrm{L}$. leucocephala soil-root systems ranged between 14.27-9.47 and 0.13-0.55 respectively. The detachment rate dramatically declined with the increase of the growth time, while the enhancement of erosion resistance significantly increased $(\mathrm{p}=0.004 ; \mathrm{p}=0.005)$ (Fig. 1). The detachment rate of eleven-month-old $\mathrm{L}$. leucocephala seedlings was lower than that of the control by $40.81 \%$, and its enhancement of erosion resistance was higher than that of 3-month-old seedlings. It indicated that 
7-month-old L. leucocephala seedlings had highest increase in erosion resistance.
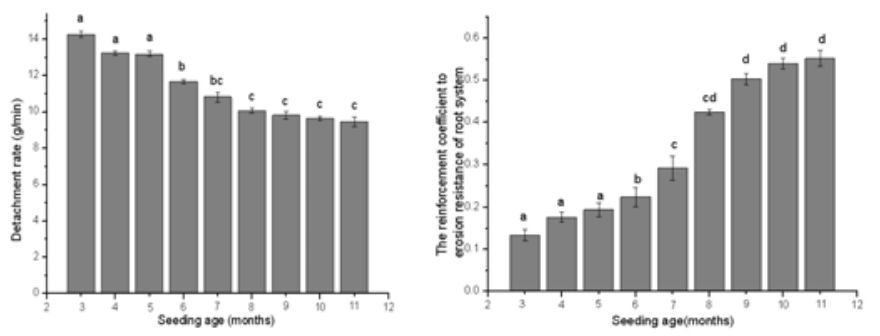

Figure 1. Effect and Variation of Erosion Resistance of Soil Root System

2) Scour Resistance of Soil Root System

Plant root system can also efficiently improve the effect of scour resistance on shallow soil layer. The scour resistance coefficient and reinforcement of $\mathrm{L}$. leucocephala seedling's soil-root systems changed at the range of $0.03-0.066$ and $0.033-0.731$ respectively. The scour resistance rate and the reinforcement dramatically improved with the increase of the growth time $(\mathrm{p}=0.007$; $\mathrm{p}=0.008$ ) (Fig. 2). The detachment rate of eleven-monthold seedling was higher than that of the control by $90.59 \%$ and was also higher than that of 3-month-old seedling by $84.29 \%$. The enhancement of scour resistance of 6-monthold seedling and 7-month-old seedlings was increased by $55.35 \%$ and $39.36 \%$ when compared with that of $7-$ month-old seedlings respectively.
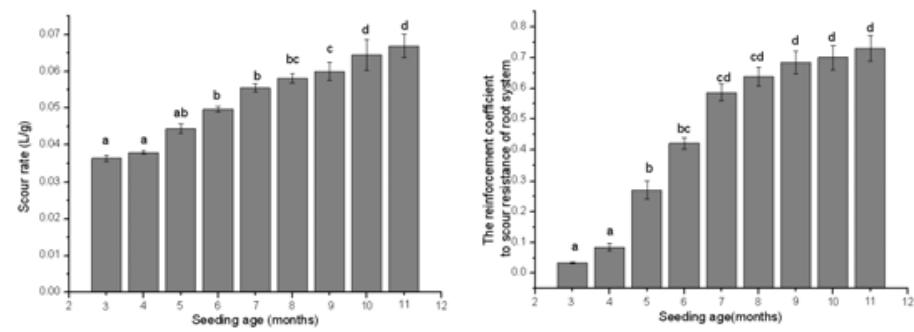

Figure 2. Effect and Variation of Scour Resistance of Soil Root System

3) Shear Strength and Tensile Strength of Soil-root System

Plant root system also efficiently improved the effect of shear strength on shallow soil layer. The tensile strength of L. leucocephala seedling's soil-root systems increased with the increase of age. Its shear strength and tensile strength were changing at the range of 12.35$33.3(\mathrm{kpa})$ and $8.59-38.53(\mathrm{~N} / \mathrm{mm} 2)$ respectively, and were improved with the increase of time $(\mathrm{p}=0.017 ; \mathrm{p}=0.03)$ (Fig. $2)$. The shear strength of 11-month-old seedlings was higher than that of the control by 226.4 and was also higher than that of 3-month-old seedlings by 169.6. The maximum enhancement value occurred in seventh month seedlings, which was $21.6 \%$ higher than that of last month seedlings. In the experiment of tensile strength, 7-monthold seedling was $348.4 \%$ higher than that of 3 -month-old seedlings. The most significant enhanced value occurred in 6-month-old seedlings, which was $38.2 \%$ higher than that of 11-month-old seedlings.

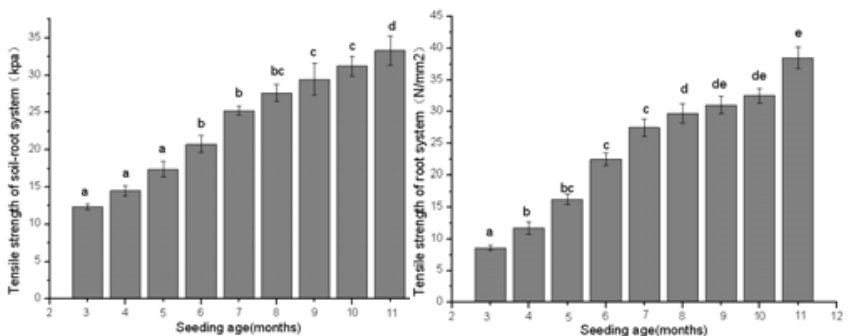

Figure 3. Effect and Variation of Shear and Tensile Strength of Soil Root System

C. The relationship of root Structure and soil reinforcement and slope protection

The enhancement of L. leucocephala seedling in soil erosion resistance, soil scour resistance and shear strength of soil-root system had a significant linear relationship with the average root biomass $(\mathrm{p}=0.001 ; \mathrm{p}=0.003$; $\mathrm{p}=0.003$ ) (Fig. 4). All of them increased with the increase of root biomass. It suggested that there were significant differences between root system organization and structure of plants in different ages. These differences led to further differences in their performance of soil root systems on soil and slope protection in shallow soil layer.
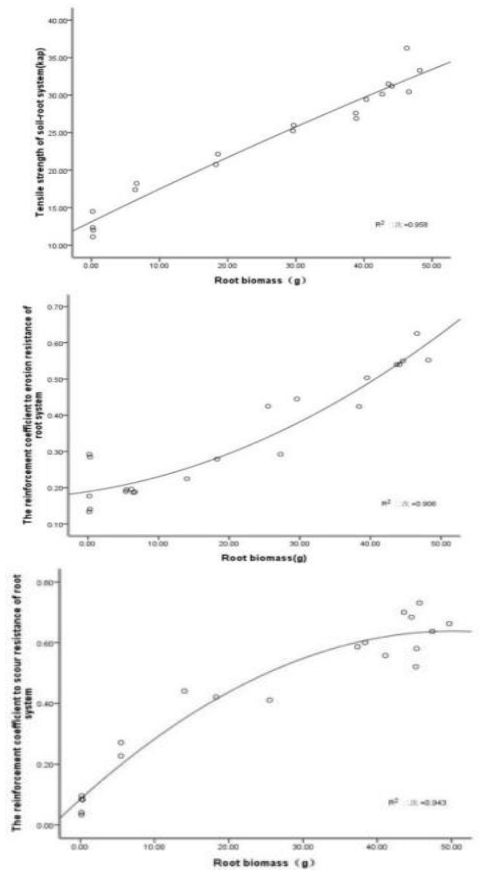

Figure 4 . Relationship Between Root Biomass and Soil Reinforcement and Slope Protection

\section{DISCUSSION}

The function of soil-root system on soil conservation and slope protection is realized by the cohesion and reinforcement of roots on soil and coordinate regulation by above ground part and root system on slope surface hydrologic process [7]. This study showed that the enhancement of erosion resistance, scour resistance and 
tensile strength of 11-month-old L. leucocephala seedlings was higher than that of 3-month-old seedling by $388.2 \%$, $211.5 \%$ and $348.4 \%$ respectively. The shear strength was $226.4 \%$ higher than that of the control. It indicated that L. leucocephala seedling had significant effects on soil conservation and slope stabilization.

Many researches suggested that there was significant correlation between root-soil system's soil and slope protection performance and root system's biological and ecological characteristics, especially spatial-temporal structure. Plant species, ages, spatial structure and ecological conditions like soil types and moisture all influence root-soil systems' soil and slope protection performance [8]. Our research also indicated that the enforcement of soil root system had a significant positive correlation with biomass. The effects of soil root system on soil conservation and slope protection increased with the seedling growing time It suggested that the growth and development of plant promote the performance of rootsoil system in soil conservation and slope protection.Seedlings grew fast in the sixth (August) and seventh month (September) during the whole experimental period as the sunshine and temperature was favorite for seedlings growth. All the growth indicators were increased most obviously. The fast growth of L. leucocephala seedlings enriched the effects of root-soil systems on soil conservation and slope protection.

\section{ACKNOWLEDGEMENTS}

This work is supported by a National Key Technology R \& D Program of China (2012BAC06B02-04)

\section{REFERENCES}

[1] Mao Rong, Meng Guang-tao, Zhou Yue, Mechanism of Plant Roots on Soil Erosion Control.Research of Soil and Water Conservation, 13(2),pp.241-241,Apr 2006.

[2] Fang Dong-Hai, Ji Zhong-Hua, The study on species diversity of Leucaea Leucocephala plantation in Jinsha River hot and dry valley.Research of Soil and Water Conservation, 12(1), pp.135-137, June 2005.

[3] Gao Jun-Qin, OuYang Hua, The study on litter decomposition and influence factors of Calamagrostis Angustifolia in Sanjiang Plain wetlands.Journal of Soil and Water Conservation. 18 (4), pp.121124,June 2004.

[4] Liu Ding-hui, LI Yong, Mechanism of Plant Roots Improving Resistance of Soil to Concentrated Flow Erosion.Journal of Soil and Water Conservation, 17(3),pp.34-37, Sep 2003.

[5] Pan Yi-Guo, Research advance on the functions of plant root system in soil anti-erodibility and anti-shear strength.Guizhou Forestry Science and Technology, 35(2),pp.10-13,Oct 2007.

[6] Yang Feng-Wei,The construction and application of strength measurement curve of abies fabric root system with pull-out method.Research of Soil and Water Conservation,4(14),pp.197199,Jan 2007.

[7] Xu Shao-Bo, Zeng Bo, Enhancement effects of 5 flooding-tolerant species' roots on soil anti-erodibility in Three Gorges Reservoir region. Journal of Soil and Water Conservation,12(6),pp.13-22,Oct 2008.

[8] Li Yong, Wu Shu-Xia, Stabilization of soil structure by roots of artificial locust trees in purple soil region.Journal of Soil and Water Yang Yong-Hong, A study of tensile strength tests of arborous species root system in forest engineering technique of shallow land slide.Research of Soil and Water Conservation. 14 (7),pp. 138140,Jun 2007.

[9] Yang Yong-Hong, Astudy of tensile sreength rests of arborous species root system in forest engineering technique of shallow land slide research of soil and water consernation.14(7),pp.138-140,jun 2007

[10] J.H. Cheng, H.J. Zhang, and W. Wang, etc. Evaluation of soil conservation capacity of five plantations in Simian Mountain, Chongqing, southwestern China, J. Journal of Beijing Forestry University. (2009)

54-59. 